\title{
The effects of training and overeducation on career mobility in a segmented labour market
}

Citation for published version (APA):

Dekker, R., de Grip, A., \& Heijke, H. (1996). The effects of training and overeducation on career mobility in a segmented labour market. Researchcentrum voor Onderwijs en Arbeidsmarkt, Faculteit der Economische Wetenschappen. ROA Research Memoranda No. 4E https://doi.org/10.26481/umaror.199604E

Document status and date:

Published: 01/01/1996

DOI:

10.26481/umaror.199604E

Document Version:

Publisher's PDF, also known as Version of record

\section{Please check the document version of this publication:}

- A submitted manuscript is the version of the article upon submission and before peer-review. There can be important differences between the submitted version and the official published version of record.

People interested in the research are advised to contact the author for the final version of the publication, or visit the DOI to the publisher's website.

- The final author version and the galley proof are versions of the publication after peer review.

- The final published version features the final layout of the paper including the volume, issue and page numbers.

Link to publication

\footnotetext{
General rights Owners
rights.

- You may freely distribute the URL identifying the publication in the public portal. please follow below link for the End User Agreement:

www.umlib.nl/taverne-license

Take down policy

If you believe that this document breaches copyright please contact us at:

repository@maastrichtuniversity.nl

providing details and we will investigate your claim.
}

Copyright and moral rights for the publications made accessible in the public portal are retained by the authors and/or other copyright owners and it is a condition of accessing publications that users recognise and abide by the legal requirements associated with these

- Users may download and print one copy of any publication from the public portal for the purpose of private study or research.

- You may not further distribute the material or use it for any profit-making activity or commercial gain

If the publication is distributed under the terms of Article $25 \mathrm{fa}$ of the Dutch Copyright Act, indicated by the "Taverne" license above, 


\section{The effects of training and overeducation on career mobility in a segmented labour market}

Ron Dekker, Andries de Grip and Hans Heijke 
The effects of training and overeducation on career mobility in a segmented labour market

Ron Dekker, Andries de Grip and Hans Heijke

ROA-RM-1996/4E

Research Centre for Education and the Labour Market

Faculty of Economics and Business Administration

University of Limburg

Maastricht, April 1996 
ISBN 90-5321-177-2 


\section{Contents}

\section{Page}

Abstract

1 Introduction 1

2 Segmentation theory 2

3 Training, overeducation and career mobility 4

4 Demarcation of the labour market segments $\quad 7$

5 Some stylized facts 11

6 Estimation results $\quad 14$

7 Conclusions 17

$\begin{array}{lr}\text { References } & 18\end{array}$ 


\begin{abstract}
This paper analyses the effects of both training and overeducation on upward mobility in the internal labour market, the professional market and the supplementary labour market. The latter segment can be considered as a broadly defined secondary labour market as it is not restricted to the low level unskilled jobs only.

As expected, 'career training' influences upward mobility positively. However, contrary to the predictions of traditional segmentation theory, this effect is only found for the workers employed in the supplementary labour market. Overeducation also affects upward mobility positively, which indicates that overeducation is to some extent a temporary phenomenon at the individual level. However, this also holds in particular in the supplementary segment of the labour market. The estimation results show that the supplementary labour market probably plays an important role in the transition process between initial education and the labour market, which means that the barriers between the supplementary and the primary labour market are less severe than segmentation theory predicts.
\end{abstract}

We would like to thank Rolf van der Velden for his comment on an earlier version of this paper. 


\section{Introduction}

Although the mainstream in human capital studies has traditionally focused on the labour income effects of human capital investments, measured by earning functions, several studies have been published more recently with regard to the effects of human capital investments on labour market mobility (see e.g. Sicherman and Galor, 1990, Prendergast, 1993). With regard to workers' on-the-job training, however, the different mobility implications of 'general' and 'firm-specific' training were identified by Becker as early as 1962. Another growing branch of human capital research concerns overeducation (see e.g. Duncan and Hoffman, 1981; Tsang and Levin, 1985; Verdugo and Verdugo, 1989; Groot, 1991 and Cohn and Khan, 1995). These studies focus particularly on the income effects of overeducation. ${ }^{1}$ It is interesting to note that both the mobility impact of training and the existence of overeducation are highly related to earlier critiques of human capital theory from the standpoint of labour market segmentation theory (see e.g. Reich et al., 1973 and Cain, 1976).

Labour market segmentation theories split the labour market up into several segments. The most common segmentation divides the market into a primary segment containing the 'good' jobs and a secondary segment with bad, unstable jobs. Several authors subdivide the primary segment further into internal labour markets (within firms) and professional markets (e.g. Doeringer and Piore, 1971; Althauser and Kalleberg, 1981). The primary and secondary labour market segments differ with respect to job characteristics such as employment stability, payment and job contents. Moreover, the segments offer employees different training and career opportunities. Firm internal labour markets offer better training facilities and internal career paths. These career paths may however imply overeducation in entry-level jobs, because workers are recruited for a career trajectory and not just for their initial job. This overeducation could diminish with internal promotions to higher job levels. On the secondary market, however, overeducation might be a more persistent phenomenon due to the assumed 'dead-end' character of the jobs in this labour market segment.

This paper will analyze the effects of both training and overeducation on upward, or 'career', mobility in the three labour market segments distinguished in labour market segmentation theory: the firm internal market, the professional market and the secondary labour market. Such an analysis, however, requires a proper demarcation of the three labour market segments, which is a considerable difficulty as there are many different descriptions of the three segments and even more variations in the features and characteristics attributed to each segment. Moreover, in defining the three labour market segments two points must be borne in mind. Firstly, since such mobility analyses have to focus on the individual level the labour market segments must be demarcated in a way

1. An exception is Alba-Ramírez (1993), who also analyzes the mobility effect of overeducation. 
which identifies which segment an individual worker is employed in (see also Wolfs, 1992). Secondly, to avoid tautological results we must avoid using criteria which are the primary focus of the analysis (differences in mobility patterns and training efforts).

The empirical demarcation of the three segments developed in this paper includes rather severe conditions for the internal labour market and the professional market, for two reasons. Firstly, this reduces the noise in the analyses of these two primary market segments, so that the secondary market is the 'residual category'. Secondly, the broader definition of the secondary labour market allows for the tendency for an increasing proportion of the jobs that require intermediate or higher educational qualification to become less attractive from a worker's point of view due to the lack of the career opportunities available on the professional or firm internal markets. A similar argument is found in the more recent literature on 'atypical employment', in which temporary and parttime jobs are also classified as secondary jobs, irrespective of the skill contents of the jobs (see e.g. Córdova, 1986, Rogers and Rogers, 1989, Treu, 1992 and Meulders et al., 1994). Although this broader definition is related to the theoretical notions underlying segmentation theory (see e.g. Piore, 1975) it may cause some confusion with the usual interpretation of the secondary labour market as the segment of the low level, unskilled jobs. Therefore, we will here label this segment as the supplementary labour market.

The remainder of the paper is organized as follows. Section 2 will briefly discuss the mobility and training characteristics of the workers on the three labour market segments as postulated in labour market segmentation theory. Section 3 discusses the expected effects of training and overeducation on upward mobility in the three labour market segments, and how temporary or persistent overeducation is in the three labour market segments. Section 4 demarcates the three labour market segments empirically, using data from the Dutch Labour Supply Survey of the Organisation for Strategic Labour Market Research (OSA). Section 5 gives some stylized facts on mobility and training for the three labour market segments, and Section 6 analyzes the estimation results on the impact of training and overeducation in the three segments, using multinomial logit analyses. Section 7 contains the conclusions.

\section{Segmentation theory}

The question whether there are several, distinctive segments on the labour market, each having its own allocation mechanism, goes back to Cairnes' (1873) non-competing groups concept. In the more recent literature the division of the labour market into segments often refers to the division of firms into a primary market, operating in the core of the economy, versus a secondary segment facing uncertain demand (see e.g. Piore, 1975, Wilkinson, 1981 and $\mathrm{Oi}, 1990)$. In the primary segment we can have various firm internal labour markets, in which the 'pricing and allocation of labour is governed by a set of 
administrative rules and procedures' (Doeringer and Piore, 1971, p. 1) and professional markets, which refer to workers in particular occupational categories whose vocational skills make them relatively independent of the firms for which they work (Doeringer and Piore, 1971; Althauser and Kalleberg, 1981).

However, the segmentation theory, because it is inductive, does not give a straightforward answer to the number of segments that should be distinguished. In practice, the segmentation depends on the type of research concerned (Wolfs, 1992), which complicates comparisons between studies. Fortunately, there is broad agreement on segmentation into three segments (see Doeringer and Piore, 1971; Lutz and Sengenberger, 1981; Wolfs, 1992). The segments are:

-firm internal labour markets;

-craft or professional markets;

-secondary markets.

The three segments have the following characteristics with respect to mobility, (over)education and training, which are the aspects considered in this paper. Firm internal labour markets offer skilled jobs which require firm-specific skills. For many jobs, on-the-job training is the most efficient was of obtained firm-specific skills. A prerequisite for this kind of training is a work structure in which the specific skills are transferred from experienced workers to new entrants. The former will only give training to the latter if they are sure they will not be fired afterwards (Thurow, 1975). Therefore, promotion (and dismissal) rules are often based on seniority. Because firm-specific training is necessary to realize the specialization of tasks, labour becomes a quasi-fixed factor of production (Oi, 1962). This fixed cost component of labour induces management to minimize labour turnover to reduce recruitment, screening and training costs (Doeringer and Piore, 1971). Upward internal mobility along a career path is characteristic for a firm internal labour market, because of its job structure. This however puts a lower limit on firm size since a firm must have a certain minimum workforce to offer internal job openings and develop rules and procedures for the allocation and pricing of jobs.

Professional markets relate to jobs that require specialized vocational training, rather than the firm-specific training on internal labour markets. These professional markets can be further categorized by job level (professional specialists versus blue collar workers), according to the bargaining power of the unions, and for self-employed versus salaried employment (Doeringer and Piore, 1971). Although there may be several competence levels within a particular trade or profession, in general internal promotions to higher job levels will be scarce. Such specialized professionals and tradesmen have short career lines. However, the general character of their skills enhances the external mobility of these workers.

The power of employees to determine their own work contents distinguishes the 
professional market from the secondary labour market. The secondary labour market is traditionally considered to consist of low level, unskilled jobs, which require no specific training. These jobs can be expected to be found in small firms (Piore, 1975; Weeks, 1980) which do not have stable product markets or the possibility of internal promotions. However, the instable product market argument means that the instable jobs are not necessary restricted to the low level jobs. As mentioned before we will therefore use a broader definition of the secondary labour market which we will label as the supplementary labour market. Due to the instable product market the jobs in this segment are relatively insecure. External mobility to other jobs in this segment will therefore be high. However, mobility to the primary labour market is hampered by the bad work habits that workers might develop in these instable jobs (Piore, 1975). Therefore neither employers nor workers are assumed to have any incentive to invest in further training.

\section{Training, overeducation and career mobility}

\section{Training}

According to human capital theory (Becker, 1962) training is an investment decision in which individuals can decide either to start working, or to invest in training and delay their labour market entry. This investment in training is paid back by higher future wages because of the higher productivity that results from the increased human capital. These higher wages must compensate for direct costs of training and the opportunity costs because of the income foregone during the training period. Training can be split up into general and specific training, in order to emphasize the difference between training which raises the productivity of the worker for a great number of firms, and firm-specific training that has no effect on workers' productivity if they switch to another firm.

In the internal labour market firms have to invest in the firm-specific training of their workers. In the professional market, where general skills dominate, the workers themselves have to invest in their additional training. Recent studies indicate however that firms also have to pay for general training, since a training course usually has both general and firmspecific aspects (OECD, 1991, Hill, 1991). This makes the theoretical distinction between general and firm-specific training less suitable for explaining the mobility processes on the labour market.

An alternative to Becker's distinction between general and specific training is a classification of training according to the purpose of the training. Leaving aside training that has no relationship with labour, Bartel (1992) distinguishes two types of formal training which can be followed after labour market entry:

- core training;

- employee development, or career training. 
Core training refers to the training which is necessary to keep up with current job requirements, which change because of technological and organizational developments. Workers on both the internal labour market and the professional market continuously face the risk of skill obsolescence due to these developments. Depreciation of knowledge will be high in technical professional markets, because of the rate of technological change, and in the internal labour market, because firm-specific skills are often restricted to the ability to operate in a particular production process. However informal on-the-job training is probably the dominant strategy to combat skill obsolescence in the internal labour market.

Core training is very important for professional workers. If workers in this market segment do not keep their human capital up to date, their employability in the professional market will decline. But low-level jobs in the secondary segment do not require core training, because job levels are low.

The purpose of career training is to prepare employees for the next step in their career (e.g. promotion within the organization). Furthermore, career training has an important side-effect: it identifies employees' potential productivity. The first reason, to prepare workers for promotion, is consistent with human capital theory. The second argument is related to screening theory (Thurow, 1975), which takes explicitly account of the employer's lack of complete information about a worker's productivity. Career training will be highly related to the internal labour market segment, because of the elaborated internal career trajectories in this market segment.

Entrants in the internal labour market are screened not only for their capacity to perform their first job adequately, but also for their further career possibilities. But the employer must rely on external signals of workers' productivity in recruiting staff. Once in the organization, this uncertainty about workers' productivity can be reduced, because workers can be monitored in their current function. Career training is another monitoring instrument. Workers with steep learning curves are contestants for promotion.

Whether career training is sufficient to secure promotion depends on the promotion regime of the organization. Rosenbaum (1984) discusses three promotion regimes, which differ in the emphasis that is put on efficiency versus opportunity. 'Opportunity' here refers to promotion opportunities which motivate personnel and thus reduce the costs of controlling the work force (Prendergast, 1993). This applies particularly in internal labour markets, where direct control is difficult to maintain. In a contest mobility regime, career prospects are offered as an important instrument for maintaining productivity and preventing shirking. Promotions are rationed, but employees can 'subscribe' for each promotion round by participating in the training courses required for promotion. The rationing of promotions in the internal labour market is caused by the relatively high 'efficiency wages', which are above equilibrium level (Wolfs, 1992). This leads to endogenous differences in mobility patterns: the current job limits the extent to which a worker's productivity can be shown. 
A sponsored mobility regime is found where training costs are high or control is easy to maintain. The emphasis is then on the cost component, and opportunity aspects are not a factor. Therefore, selection takes place only at the beginning of a career. A sponsored mobility regime can be found in professional markets where training costs are high. After the first and only selection round, the limited promotion opportunities are not dependent on participation in further training.

Finally, the tournament regime is a mixture of the first two regimes. It contains both efficiency and opportunity aspects. Workers may apply for successive promotions in a way analogous to the knock-out system in a sports tournament. In a tournament mobility regime, which is again found mainly in internal labour markets, training is given to sufficient workers to create a surplus of candidates for promotion (to create a surplus). Employers then determine which workers will be selected for further promotions (Rosenbaum, 1984). Workers who fail may be required to move laterally or to leave the organization entirely.

Unskilled jobs in the supplementary segment do not offer upward promotion possibilities within the firm. But, especially for skilled newcomers on the labour market, the supplementary segment might be a useful route towards the primary segment. In that case something like a contest mobility regime rules the market in which workers in the supplementary segment try to find a good, stable and well-paid job in the internal or professional segments of the labour market (see also Lynch, 1993).

It can be concluded that career training can have two different effects in the internal labour market. It may immediately increase the probability of upward mobility (internal promotion opportunities in particular), or it may be a necessary pre-requisite for promotion and not in itself sufficient to ensure promotion. In the latter case there are more employees attending career training than there are opportunities for promotion. However, workers employed in supplementary jobs may also participate in career training. In as much as the supplementary labour market also employes skilled new entrants in the labour market who are still searching for a job opening in the internal or professional labour market, career training may also be a means to increase the probability of upward mobility towards these labour market segments. ${ }^{2}$

\section{Overeducation}

Overeducation emerges as the educational level of a worker exceeds the level of the job he or she works in. This may be inefficient with respect to the labour market allocation, but when employers are confronted with uncertainty about a worker's productivity,

2. If firms have no incentives to invest in the career training of workers employed in the supplementary segments, the workers who search for a job opening in the primary market will probably invest themselves in their career training. 
overeducation may serve as an indicator of potential productivity (see also Sicherman and Galor, 1990). In the internal labour market overeducation is normal at labour market entry, but it should reduce as internal promotions take place. In the professional market we may expect little overeducation, because of the close relationship between vocational training and the job. Overeducation may perhaps occur if a worker starts as a trainee and has to acquire additional professional skills on-the-job.

Overeducation will be highest in the supplementary labour market. Firstly, because it contains low level jobs in which 'statistically discriminated' or stigmatized workers are overrepresented (Thurow, 1975). Secondly, because overeducation will result where more highly skilled workers accept low level jobs as initial employment, from which they will continue to search for an opening on the internal or professional markets. Labour market segmentation theory traditionally assumes that overeducation is a persistent phenomenon in the secondary labour market, because workers employed in these jobs develop bad work habits that make them unsuitable for primary sector jobs. The 'dead-end' character of the secondary jobs may be strengthened by stigmatization of the workers employed in these jobs. However supplementary jobs are also the starting jobs for new entrants on the labour market who are still searching for a job opening on the internal labour market. In fact it may be that the 'waiting room' role of the supplementary market is a recent general tendency in the allocation process on the labour market (see also Lynch, 1993). Treu (1992) even states that secondary jobs have become the normal mode of entry into the labour market for young workers. In that case, upward mobility from 'starters' in the supplementary labour market to the internal or professional market may also be expected. It can be concluded that overeducation in the internal labour market is expected to be a temporary entry-level phenomenon that diminishes in the course of a worker's career due to internal upward mobility. However, overeducation might also diminish with upward mobility in the supplementary labour market, in so far as supplementary jobs are the starting jobs of skilled entrants to the labour market.

\section{Demarcation of the labour market segments}

Since our mobility analysis focuses on the individual level, it was necessary to demarcate the three labour market segments in such a way that it would be possible to identify which labour market segment an individual worker was employed in. We could not define these segments using the criteria that are the subject of our research (mobility and training), or the conclusions would have been tautological. We also did not use the personal characteristics of the workers that were expected to be over-represented in a particular labour market segment, but rather structural characteristics of jobs and firms, because the demarcation lines between segments reflect differences in demand-driven allocation rules in the labour market. 
As mentioned in Section 1, we applied rather severe conditions in defining the firm internal labour market and the professional market, and a definition of the supplementary labour market which is broader than that used in the traditional interpretation of the secondary labour market in labour market segmentation theory.

For these reasons we defined the three segments by means of three characteristics:

- the craft component: close relation between training and occupation (or selfemployment);

- the job level;

- the firm size

We demarcate the professional market first of all by the strong relationship between training and occupation that is characteristic for crafts or professions that require a particular vocational training. Vocational training then serves as a guarantee of skills and productivity (Mintzberg, 1983). In practice particular credentials are prerequisites for entry to some professional markets (doctors, nurses, teachers, advocates). The professional market covers the 'liberal' professions, blue-collar specialists and self-employed independent workers.

To measure the relationship between an occupation and a particular vocational training we computed an educational dispersion index with respect to the educational backgrounds of the workers in the occupation concerned (the index is the Gini-Hirschman dispersion index; see De Grip and Heijke, 1988). ${ }^{3}$

$$
E S_{o}=\left(1-\sum_{e=1}^{E}\left(\frac{N W_{o e}}{N W_{o}}\right)^{2}\right) \cdot \frac{E}{E-1}
$$

with:

$\begin{array}{ll}\mathrm{ES}_{\mathrm{o}} & =\quad \text { Dispersion index of educational qualifications in occupation o; } \\ \mathrm{NW}_{\mathrm{oe}} & =\quad \text { Number of workers in occupation o with education e; } \\ \mathrm{NW}_{\mathrm{o}} & =\quad \text { Number of workers in occupation o; } \\ \mathrm{E} & =\quad \text { Number of educational qualifications. }\end{array}$

3. This index is based on national Labour Force Survey data from Statistics Netherlands. 
Table 1

Occupational classes with a very low or low dispersion index of the educational qualification of the workforce

Very low dispersion index

$\begin{array}{ll}\text { Dentists and dental specialists } & 0.01\end{array}$

$\begin{array}{ll}\text { Vetinary surgeons } & 0.04\end{array}$

$\begin{array}{ll}\text { Physicians, medical specialists, pharmacists } & 0.14\end{array}$

$\begin{array}{ll}\text { Pharmacy assistants, opticians and orthopaedists } & 0.24\end{array}$

$\begin{array}{ll}\text { Primary and special education teachers } & 0.24\end{array}$

Legal professionals $\quad 0.36$

$\begin{array}{lr}\text { Registered nurses, district nurses and midwives } & 0,54\end{array}$

$\begin{array}{ll}\text { Agricultural specialists } & 0.54\end{array}$

Intermediate electrical engineers $\quad 0.56$

Surveyors, quantity surveyors, work clerks, construction technicians 0.58

$\begin{array}{ll}\text { Pastoral vocations } & 0.59\end{array}$

Low dispersion index

$\begin{array}{ll}\text { Electricians and electrical and telecommunication servicemen } & 0.61\end{array}$

$\begin{array}{ll}\text { Physiotherapists and occupational therapists } & 0.62\end{array}$

$\begin{array}{ll}\text { Police, fire and security officers } & 0.62\end{array}$

$\begin{array}{ll}\text { Technical draughtsmen } & 0.62\end{array}$

Automobile and (motor) cycle mechanics $\quad 0.64$

$\begin{array}{ll}\text { Higher electrical engineers } & 0.64\end{array}$

Architects, civil engineers and city planners $\quad 0.65$

$\begin{array}{ll}\text { Textile production workers } & 0.65\end{array}$

$\begin{array}{ll}\text { Secondary and tertiary education teachers } & 0.66\end{array}$

$\begin{array}{ll}\text { Hairdressers and beauticians } & 0.67\end{array}$

$\begin{array}{ll}\text { Carpenters and woodworkers } & 0.67\end{array}$

$\begin{array}{ll}\text { Plumbers and sanitation serviceman and installers } & 0.67\end{array}$

$\begin{array}{ll}\text { Social scientists } & 0.67\end{array}$

Higher mechanical engineers $\quad 0.68$

$\begin{array}{ll}\text { Community workers, probation officers } & 0.68\end{array}$

$\begin{array}{ll}\text { Construction workers, road construction and maintenance workers } & 0.68\end{array}$

Lathe operators, sheet-metal workers, tool and model makers $\quad 0.69$

$\begin{array}{ll}\text { Forklift drivers } & 0.70\end{array}$

$\begin{array}{ll}\text { Welders and engineering workers } & 0.70\end{array}$

Table 1 contains the occupations which have a very low or low dispersion index. ${ }^{4}$ For these occupation the $E S_{0}$, measured on a scale from 0 (no dispersion) to 1 (maximum dispersion), is less than or equal to 0.70 . We assume that the professional market also includes the self-employed independant workers, as self-employment usually refers to

4. The very low and low indices represent the lowest $10 \%$ and $20 \%$ deciles of the dispersion distribution, respectively. 
professions which require a particular vocational qualification. The self-employed are identified directly from the Labour Supply Survey data produced by the Dutch OSA which we use for the mobility analysis.

Next we determine the internal labour market by means of firm size. Following Doeringer and Piore (1971), an organization has to have a minimum size to develop rules and procedures for job allocation. Moreover, only large firms are in a position to offer internal promotions. We set the cut-off point of large firms at 50 workers. ${ }^{5}$

An additional criterion needed to distinguish the internal labour market from the supplementary market is the job level. Unskilled jobs are excluded from the internal labour market, because it is assumed that these jobs do not have access to an internal career path. The job level is determined by means of the Dutch 'Arbvo' job classification, in which jobs are assigned skill levels on a 7-point scale ranging from unskilled work, for which only a few days training is required (rated 1), to scientific work which requires two years of specific training (rated 7). Low level jobs are those rated 1 and 2. According to the Dutch Labour Force Survey of $1990,27 \%$ of the working population is employed at these lowest job levels. Using this criterion, we exclude low-level jobs in large firms as well as all jobs in small firms from the internal labour market (see also Piore, 1975).

Figure 1 gives an overview of the way in which the three labour market segments are identified.

Figure 1

Demarcation of the labour market segments

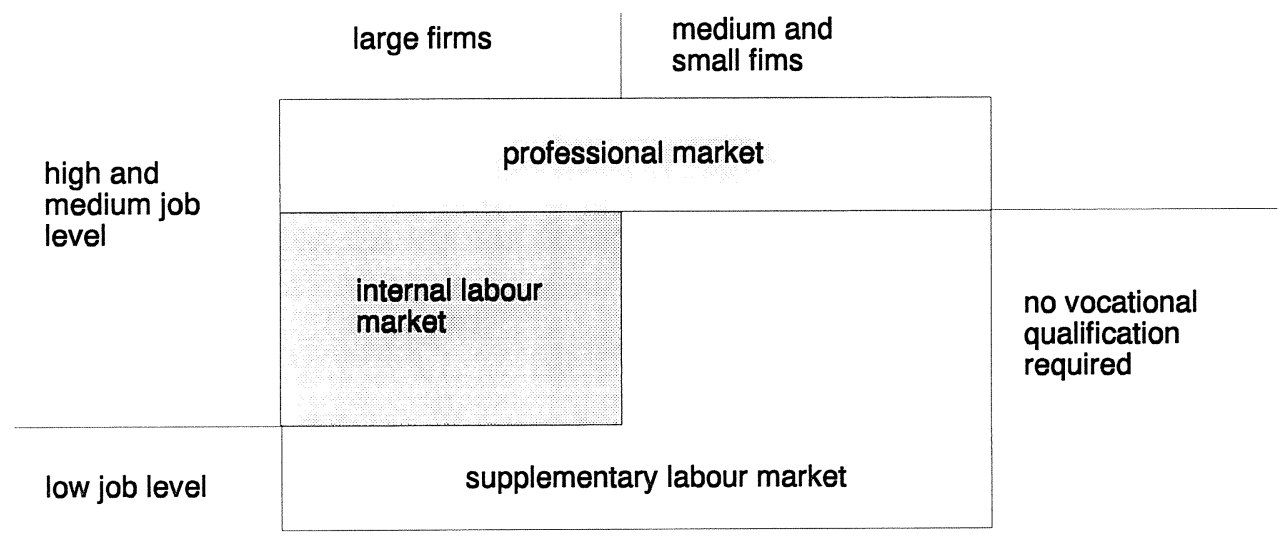

5. Changing the firm size criterion by minus or plus 10 workers changes the extent of the internal labour market segment by -4 and +2.5 percentage points, respectively. 
Table 2 shows that when we apply the above mentioned demarcation lines to the available OSA Labour Supply Surveys since 1985, the employment shares of the three labour market segments prove to have been rather stable since the middle of the 1980s. The two primary labour market segments each hold about $25 \%$ of the total working population, while the broadly defined secondary labour market employs about $50 \%$ of the total workforce. More detailed information shows that highly-skilled workers are strongly overrepresented in the professional market and to a lesser extent in the internal labour market, whereas low-skilled workers are over-represented in the supplementary labour market.

Table 2

Employment shares of the three labour market segments, 1985-1992

\begin{tabular}{lccc}
\hline & \multicolumn{3}{c}{ Labour market segment } \\
Year & $\begin{array}{c}\text { Internal labour } \\
\text { market } \\
\%\end{array}$ & $\begin{array}{c}\text { Professional market } \\
\%\end{array}$ & $\begin{array}{c}\text { Supplementary } \\
\text { market } \\
\%\end{array}$ \\
\hline & & $\%$ & \\
1985 & 25.4 & 27.7 & 46.9 \\
1988 & 27.0 & 28.0 & 45.0 \\
1990 & 26.7 & 24.8 & 48.5 \\
1992 & 24.6 & 26.5 & 48.9 \\
\hline
\end{tabular}

\section{Some stylized facts}

Before going into the results of the mobility analyses we will present some stylized facts on mobility, training and overeducation in the three labour market segments. In our empirical analysis mobility refers to job-to-job mobility only. Upward mobility is defined as job-to-job mobility that results in an increase in the job level of the worker, measured on the 7 pointscale job classification mentioned in section 4 . This measure has the disadvantage that small steps on a job ladder within the same occupational group are not measured. ${ }^{6}$ Lateral mobility is simply defined as job-to-job mobility that does not imply an upward career step. Training is differentiated into career training and core training. Career training is defined as participation in training courses lasting at least one month and on a qualification level at least as high as the initial education of the worker concerned, as in that case one may expect that this training has a substantial effect on a worker's skills. The remaining training courses are defined as core training.

6. Unfortunately, the available data do not allow for a measure that also registers the small steps on a job ladder. 
Table 3 shows the upward and lateral mobility on the three labour markets during the twoyear period, 1990-1992. Upward mobility on the internal labour market is higher than on the professional market but, remarkably, upward mobility in the secondary segment is even higher. This may be due to the large group of young people, who are just starting their careers, in this segment. However since upward mobility is defined as an increase in job level on a 7-point scale, which involves a rather large promotion, actual upward mobility is probably under-reported. Promotions can take place in rather small steps (see also Lynch, 1993) without any change of occupational group, especially on the internal labour market.

Table 3

Upward and lateral mobility by labour market segment, 1990-1992

\begin{tabular}{lcccc}
\hline & $\begin{array}{c}\text { All } \\
\text { segments } \\
\%\end{array}$ & $\begin{array}{c}\text { Internal } \\
\text { labour market } \\
\%\end{array}$ & $\begin{array}{c}\text { Professional } \\
\text { market } \\
\%\end{array}$ & $\begin{array}{c}\text { Supplementary } \\
\text { labour market } \\
\%\end{array}$ \\
\hline $\begin{array}{l}\text { Upward } \\
\text { Lateral }\end{array}$ & 8.0 & 8.2 & 3.7 & 10.9 \\
\hline
\end{tabular}

Table 4 shows that the participation rates in training activities in the three labour market segments in the period 1990-1992. As expected, the participation in training is the highest on the internal labour market, whereas it is the lowest on the supplementary market. This holds for both career and core training. However, the difference in the training participation rates between the internal and the supplementary labour market is the largest for core training.

Table 4

Participation in career training and core training by labour market segment, 1990-1992

\begin{tabular}{lcccc}
\hline & $\begin{array}{c}\text { All } \\
\text { segments } \\
\%\end{array}$ & $\begin{array}{c}\text { Internal } \\
\text { labour market } \\
\%\end{array}$ & $\begin{array}{c}\text { Professional } \\
\text { market } \\
\%\end{array}$ & $\begin{array}{c}\text { Supplementary } \\
\text { labour market } \\
\%\end{array}$ \\
\hline Career training & 10.0 & 12.6 & 10.0 & 8.0 \\
Core training & 16.6 & 22.7 & 17.9 & 11.1 \\
\hline
\end{tabular}

Table 5 seems to confirm the hypothesis that career training enlarges upward mobility possibilities. The table shows, remarkably, that the effect of career training on upward mobility is most explicit in the supplementary market, where $34 \%$ of the workers who participated in career training showed upward mobility. However, as shown in table 4, in the supplementary market fewer workers participate in career training. 
Table 5

Mobility of participants and non-participants in training by labour market segments, 1990-1992

\begin{tabular}{lcccc}
\hline & $\begin{array}{c}\text { All } \\
\text { segments } \\
\%\end{array}$ & $\begin{array}{c}\text { Internal } \\
\text { labour market } \\
\%\end{array}$ & $\begin{array}{c}\text { Professional } \\
\text { market } \\
\%\end{array}$ & $\begin{array}{c}\text { Supplementary } \\
\text { labour market } \\
\%\end{array}$ \\
\hline Upward mobility & & & & \\
No training & 7.5 & 7.8 & 3.6 & 9.7 \\
Career training & 16.4 & 7.7 & 7.9 & 34.1 \\
Core training & 5.4 & 9.6 & 1.5 & 3.3 \\
Lateral mobility & & & & \\
& & & & 28.4 \\
No training & 29.3 & 31.3 & 28.8 & 13.6 \\
Career training & 20.9 & 23.1 & 26.3 & 32.8 \\
Core training & 33.2 & 30.9 & 36.8 & \\
\hline
\end{tabular}

Remarkably, career training seems to have almost no effect on upward mobility in the internal labour market. This supports the idea that although the internal labour market offers numerous training opportunities, promotions are rationed by means of a contest mobility regime. Because of the high rate of participation in training we do not find a correlation between training and promotion. However, as mentioned before, these results may be affected by the under-reporting of smaller upward steps on the organizational hierarchies because of the way we have defined upward mobility. Table 5 also shows a positive relation between core training and lateral mobility, while career training and lateral mobility are negatively correlated.

Table 6

Age structure of overeducation by labour market segment, 1990

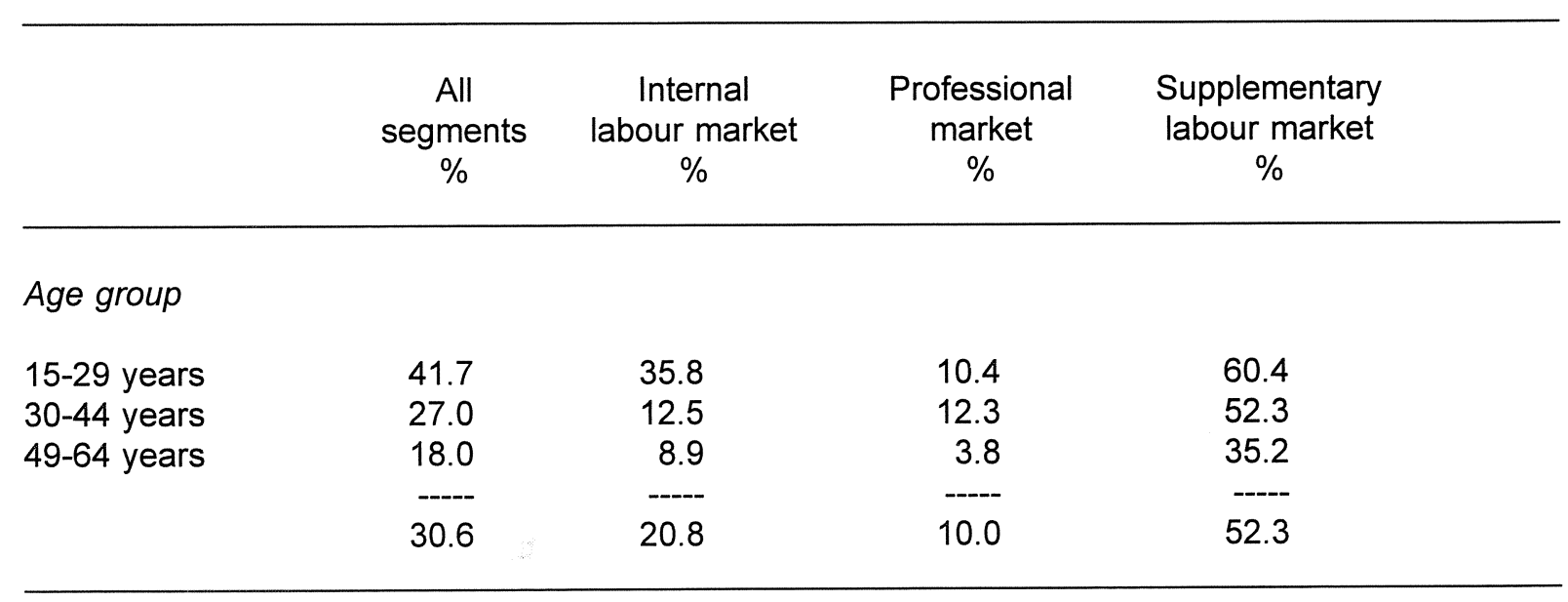


Table 6 shows that, as might be expected, overeducation is lower on the professional market than on the internal labour market, and is very high on the supplementary market. Overeducation is also concentrated among the younger workers, with the overeducation percentages falling considerably with age. This is particular true in the internal labour market, which suggests that in this labour market segment overeducation is largely a temporary phenomenon for individual workers.

\section{Estimation results}

Table 7 shows the results of multinomial analyses with regard to lateral and upward mobility. We define three possible states:

P1: laterally mobile;

P2: upwardly mobile;

P3: not mobile (the reference category).

In logit analysis, two alternatives are estimated with respect to a third, which is the reference category (Amemiya, 1981). This guarantees that the sum of the probabilities will be 1 , in contrast to a simple linear regression model. However, the interpretation of the parameter values is more cumbersome in logit analysis than in linear regression, because the effect of a parameter depends on the value of the exogenous variable and the parameter outcome is relative to the reference category.

In addition to the explanatory variables that enable us to test the effects of training and overeducation on the mobility processes in the various labour market segments, we incorporated some personal characteristics that are usually expected to affect labour market mobility - gender, age and skill level. Moreover, we corrected for the tenure effects that may be expected ${ }^{7}$ and the possible effects of part-time work.

The 'all segments' estimation results show that upward mobility on the internal labour market is not significantly higher than in the supplementary segment (the reference category). This unexpected result might be due to under-reporting of upward mobility on the internal labour market as a result of the use of a 7-point job level scale that does not measure smaller career steps and the underreporting of upward mobility of high skilled workers employed at the highest job level. Upward mobility on the professional market is significantly lower than in the supplementary segment. This indicates the 'waiting room' role of the supplementary labour market for new entrants in the labour market who are still searching for a job opening in the primary segments of the labour market.

7. Both the human capital theory and job matching theory predict a negative relationship between age or tenure and external mobility. 
As expected, career training influences upward mobility positively. However it was remarkable that this effect was only found on the supplementary market. The significant effect of career training on upward mobility for the supplementary segment indicates that career training on this segment is a means of gaining promotion to a higher-level job in the primary segments. This result contradicts traditional segmentation theory, which emphasizes the ineffectiveness of human capital investments for workers employed in the secondary labour market segment. However, the result is in accordance with the findings of Lynch (1993). The insignificant effect of career training on the internal labour market can be explained by the fact that primary (promotion) jobs are rationed in what Rosenbaum characterizes as a contest or tournament mobility regime: career training on the internal labour market is not a sufficient condition for promotion.

Overeducation has the expected positive effect on upward mobility, although the parameter is not significant for the internal labour market. Perhaps the reasoning used to explain the lack of a significant effect of career training in the internal market segment also applies to overeducation in that segment. This would mean that overeducation is to some extent a temporary phenomenon for individuals in that segment. However, the same reasoning would apply even more strongly to the supplementary labour market and the professional market.

The remaining estimation results show that women and part-time workers are more often laterally mobile, again indicating their weak labour market positions. On the professional market, working part-time does not have the expected negative effect on mobility, but mobility is generally lower in this segment. The same applies for younger workers on the internal labour market and the supplementary segment. Older workers have lower lateral and upward mobility in all segments.

Workers with higher education are more laterally mobile. We presume that this does not follow from a weak labour market position, but that by our definition of upward mobility (an increase in function level) highly-educated workers (who are not overeducated) have by definition fewer promotion possibilities.

Job tenure has a negative influence on both lateral and upward mobility in the supplementary segment. This points to the process of matching workers and jobs which might be expected from matching theory (Jovanic, 1979), or indicates that workers mobility is inhibited if they stay too long in one job: they become trapped in their current function . 
Table 7

Logit estimation of lateral and upward mobility

\begin{tabular}{|c|c|c|c|c|c|c|c|c|}
\hline & \multicolumn{2}{|c|}{ All segments } & \multicolumn{2}{|c|}{ Internal segment } & \multicolumn{2}{|c|}{ Professional market } & \multicolumn{2}{|c|}{$\begin{array}{l}\text { Supplementary } \\
\text { segment }\end{array}$} \\
\hline & value & t-ratio & value & t-ratio & value & t-ratio & value & t-ratio \\
\hline \multicolumn{9}{|l|}{ Upward mobility } \\
\hline Constant & $-1.98^{* *}$ & -5.60 & $-2.22^{* *}$ & -3.74 & $-3.22^{\star *}$ & -4.40 & $-1.76^{\star \star}$ & -3.93 \\
\hline Female & 0.05 & 0.20 & 0.34 & 0.78 & 0.31 & 0.42 & -0.40 & -1.04 \\
\hline Young & 0.27 & 1.14 & 0.49 & 1.10 & 0.77 & 1.17 & 0.16 & 0.49 \\
\hline Old & $-0.81^{* *}$ & -1.98 & -1.76 & -1.64 & -0.22 & -0.24 & -0.67 & -1.26 \\
\hline Part-time & -0.11 & -0.36 & 0.05 & 0.09 & -0.66 & -0.69 & 0.12 & 0.28 \\
\hline Low skilled & -0.02 & -0.07 & 0.23 & 0.45 & -0.74 & -0.98 & -0.02 & -0.07 \\
\hline Highly skilled & -0.02 & -0.05 & 0.09 & 0.15 & 0.24 & 0.34 & -0.21 & -0.31 \\
\hline Career training & $0.66^{* *}$ & 2.33 & -0.31 & -0.52 & 0.47 & 0.64 & $1.26^{* *}$ & 3.16 \\
\hline Core training & -0.31 & -0.92 & 0.12 & 0.28 & -1.36 & -1.23 & -1.11 & -1.47 \\
\hline Overeducation & $0.66^{* *}$ & 2.70 & 0.44 & 0.88 & $1.29 *$ & 1.85 & $0.70^{* *}$ & 2.09 \\
\hline Tenure & $-0.04^{*}$ & -1.88 & -0.03 & -0.79 & 0.02 & 0.57 & $-0.07^{* *}$ & -2.09 \\
\hline Internal segment & -0.03 & -0.11 & - & - & - & - & - & - \\
\hline Professional market & $-0.77^{\star *}$ & -2.24 & - & - & - & - & - & - \\
\hline \multicolumn{9}{|l|}{ Lateral mobility } \\
\hline Constant & $-0.74^{* *}$ & -3.58 & $-1.17^{* *}$ & -3.31 & $-0.52^{*}$ & -1.87 & $-0.90^{* *}$ & -2.89 \\
\hline Female & $0.29^{*}$ & 1.78 & 0.36 & 1.25 & 0.23 & 0.72 & 0.31 & 1.14 \\
\hline Young & $0.61^{* *}$ & 4.07 & $0.90^{* *}$ & 3.13 & -0.18 & -0.65 & $0.93^{* *}$ & 3.72 \\
\hline Old & $-0.43^{* *}$ & -2.15 & -0.50 & -1.31 & -0.50 & -1.51 & -0.32 & -0.95 \\
\hline Part-time & $0.42^{\star *}$ & 2.31 & $0.71^{* *}$ & 2.13 & 0.13 & 0.39 & $0.55^{*}$ & 1.85 \\
\hline Low skilled & -0.20 & -1.29 & -0.45 & -1.49 & -0.30 & -1.07 & 0.08 & 0.34 \\
\hline Highly skilled & $0.37^{* *}$ & 2.00 & $0.76^{* *}$ & 2.39 & -0.07 & -0.24 & 0.58 & 1.43 \\
\hline Career training & -0.39 & -1.64 & -0.52 & -1.36 & -0.06 & -0.14 & -0.61 & -1.24 \\
\hline Core training & 0.07 & 0.40 & -0.11 & -0.40 & 0.28 & 0.94 & 0.11 & 0.33 \\
\hline Overeducation & $-0.57^{* *}$ & -3.53 & -0.36 & -1.14 & -0.59 & -1.36 & $-0.77^{* *}$ & -3.50 \\
\hline Tenure & $-0.02^{* *}$ & -2.10 & 0.00 & 0.15 & -0.02 & -0.97 & $-0.06^{* *}$ & -2.58 \\
\hline Internal segment & -0.07 & -0.45 & - & - & - & - & - & - \\
\hline Professional market & -0.18 & -1.06 & - & - & - & - & - & - \\
\hline -Log Likelihood & \multirow{2}{*}{\multicolumn{2}{|c|}{$\begin{array}{l}-1,066,799 \\
1,343\end{array}$}} & \multirow{2}{*}{\multicolumn{2}{|c|}{$\begin{array}{l}-329,696 \\
414\end{array}$}} & \multirow{2}{*}{\multicolumn{2}{|c|}{$\begin{array}{l}-272,451 \\
380\end{array}$}} & \multirow{2}{*}{\multicolumn{2}{|c|}{$\begin{array}{l}-432,886 \\
549\end{array}$}} \\
\hline $\mathrm{N}$ & & & & & & & & \\
\hline
\end{tabular}




\section{Conclusions}

This paper has analyzed the role of training in career mobility processes and the persistence of overeducation in three labour market segments: the (firm) internal labour market, the professional labour market and the supplementary labour market. The latter segment can be considered as a broadly defined secondary labour market, as it is not restricted to the low level, unskilled jobs only.

With respect to mobility we did not find the expected high rate of upward mobility on the internal labour market, which may point to the rationing of promotions on this labour market segment. However the under-reporting in our analysis of 'small steps' upward mobility in the internal labour market may be another explanation. As expected, there is much less upward mobility in the professional market than in the internal labour market, which confirms that career ladders in professional markets are rather flat. On the one hand this indicates a good match between workers and jobs. The selection process in this segment probably takes place within initial vocational education, before labour market entry. On the other hand, it may also indicate that workers are quickly trapped in the jobs they hold job, and have hardly any career opportunities. Upward mobility is also high in the supplementary market, which indicates that there are career opportunities for workers who start their working lives in the supplementary labour market. Lateral mobility is concentrated among the workers with weak labour market positions, in particular women, young people, older workers and part-timers. Highly skilled workers also have high lateral mobility. Overeducated workers show less lateral mobility, and longer tenure also lowers the probability of lateral mobility.

The results of our mobility analyses show that career training has little effect on the upward mobility of workers in the internal labour market. Career training in the internal labour market does not seem to be a sufficient condition for promotion, indicating that promotions are rationed in what Rosenbaum (1984) characterizes as a contest mobility regime. However there is a close relationship between career training and upward mobility in the supplementary segment. This result contradicts traditional segmentation theory, which emphasizes the ineffectiveness of human capital investments in the supplementary labour market. It is, however, in accordance with the findings of Lynch (1993). The relevance of career training for promotions in the supplementary labour market may also indicate that in this segment formal training performs the role which on-the-job training plays in the internal labour market.

Overeducation has a positive effect on upward mobility, although this effect is not significant for the internal labour market, which is remarkable. Like career training, overeducation is apparently not a sufficient condition for promotion in the internal labour market. Overeducation is highest among younger workers and diminishes with age, which indicates that it is not a structural situation for individual workers. The fact that 
overeducation was found to have a positive effect on upward mobility does show that it is to some extent a temporary phenomenon at the individual level, despite the unexpected finding that this positive effect is strongest in the supplementary and professional labour markets.

Altogether, it may be concluded that the supplementary labour market has probably become an important route in the transition between initial education and the labour market. School-leavers who accept entry jobs in the supplementary segment which are below their educational level are not stuck in these jobs, but climb to higher job levels later in their careers. Moreover, the barriers between the supplementary and the primary labour market segments have become less severe than segmentation theory predicts, since the human-capital investments of workers employed in the supplementary segment do enable them to climb the occupational ladder.

\section{References}

Alba-Ramírez, A. (1993), Mismatch in the Spanish Labor Market: Overeducation?, Journal of Human Resources, Vol. 28, No. 2, 259-278.

Althauser, R.P., A.L. Kalleberg (1981), Firms, Occupations and the Structure of Labor Markets: A Conceptual Analysis, Sociological Perspectives on Labor Market, Academic Press, Orlando, 14831536.

Amemiya, T (1981), Qualitative Response Models: a Survey, Journal of Economic Literature, Vol. 19, 1483-1536.

Bartel, A.P. (1992), Training, Wage Growth and Job Performance: Evidence from a Company Database, NBER Working paper, no 4027, Cambridge, Mass.

Becker, G. (1962), Human Capital: A Theoretical and Empirical Analysis, Journal of Political Economy, Vol. 70 , No. 5, 9-46

Cohn, E. and S.P. Khan (1995), The wage effects of overschooling revisited, Labour Economics, Vol. 2, No. 1, 67-77.

Córdova, E. (1986), From full-time employment to atypical employment: A major shift in the evolution of labour relations?, International Labour Review, Vol. 125, 641-657.

Cain, G.C. (1975), The challenge of dual and radical theories of the labor market to orthodox theory, Journal of Economic Literature, Vol. 65, No. 2 (May), 16-22.

Cairnes, J.E. (1873), Some Leading Principles of Political Economy Newly Expounded, MacMillan, London.

Doeringer, P.B., M.J. Piore (1971), Internal labor markets and manpower analysis, Lexington Books, Heath, Lexington.

Duncan, G.J., S.D. Hoffman (1981), The Incidence and Wage Effects of Overeducation, Economics of Education Review, Vol. 1, 57-83.

Grip, A. de, J.A.M. Heijke (1988), Labour Market Indicators: an Inventory, ROA-W-1988/1E, ROA, Maastricht.

Groot, W (1991), 'Overeducation and the returns to enterprised-related schooling', Economics of Education Review, Vol. 12, 299-309.

Hill, E.T., (1991), 'Post-secondary vocational education and on-the-job training', Applied Economics, Vol. 23, 197-208.

Jovanic, B. (1979), Job Matching and the Theory of Turnover, Journal of Political Economy, Vol. 87, no. $5,972-990$.

Lutz, B., W. Sengenberger (1974), Arbeitsmarktstrukturen und öffentliche Arbeitsmarktpolitik, Otto Schwartz \& Co, Göttingen. 
Lynch, L.M. (1993), Entry-level Jobs: First Rung on the Employment Ladder or Economic Dead End?, Journal of Labor Research, Vol. 14, No. 3, 249-263.

Meulders, D., O, Plasman, R. Plasman (1994), Atypical Employment in the EC, Aldershot, Darthmouth.

Mintzberg, H. (1983), Structure in fives: designing effective organizations, Prentice-Hall International, Englewood Cliffs.

OECD (1991), Employment outlook, July 1991, OECD, Paris.

Oi, W.Y (1962), 'Labor as a Quasi-Fixed Factor', Journal of Political Economy, Vol. 70, 538-555.

Oi, W.Y. (1990), 'Employment Relations in Dual Labor Markets', Journal of Labor Economics, Vol. 8, 124-129.

Piore, M.J. (1975), 'Notes for a Theory of Labor Market Stratification', in: R.D. Edwards, M. Reich, D.M. Gordon (eds), Labor Market Segmentation, Lexington Books, London, 125-150.

Prendergast, C. (1993), The role of promotion in inducing specific human capital acquisition, The Quarterly Journal of Economics, May 1993, 523-534.

Reich, M., D.M. Gordon, R.C. Edwards (1973), A Theory of Labor Market Segmentation, American Economic Review, Vol. 63, No. 2 (May), 359-365.

Rodgers, G., J. Rodgers (eds) (1989), Precarious jobs in labour market regulation: The growth of atypical employment in Western Europe, Geneva, International Institute for Labour Studies.

Rosenbaum, J.E. (1984), Career Mobility in a Corporate Hierarchy, Academic Press, Orlando.

Sicherman, N., O. Galor (1990), A theory of career mobility, Journal of Political Economy, Vol. 98, 169-192.

Thurow, L.C. (1975), Generating inequality, Macmillan, New York.

Treu, T. (1992), Labour flexibility in Europe, International Labour Review, Vol. 131, Nos 4-5, 497512.

Tsang, M., H. Levin (1985), The Economics of Overeducation, Economics of Education Review, Vol. 4, 93-104.

Verdugo, R., N. Verdugo (1989), The impact of surplus schooling on earnings: some additional findings, Journal of Human Resources, Vol. 24, 629-643.

Wilkinson, F. (1981), The dynamics of labour market segmentation, Academic Press, London.

Williamson, O.E. (1975), Markets and Hierarchies: Analysis and Antitrust Implications, The Free Press, New York.

Wolfs, G. (1992), Firm internal labour markets in the Netherlands, a contract-theoretical approach, Dissertation nr. 92-6, Faculty of Economics and Business Administration University of Limburg, Maastricht. 




Research Centre for Education and the Labour Market

P.O. Box 616

6200 MD Maastricht

The Netherlands

Telephone: +31433883647/ 3883751

Telefax: $\quad+31433210999$

E-mail: secretary@roa.rulimburg.nl

University of Limburg

Faculty of Economics and Business Administration 